\title{
PERBEDAAN PERILAKU MASYARAKAT DALAM GERAKAN MASYARAKAT HIDUP SEHAT (GERMAS) DAERAH RURAL DAN URBAN
}

\author{
Yulia Susanti ${ }^{1}$, Ria Septiyana², Sekar Ella Praditta1 \\ 1 Program Studi Sarjana Keperawatan Sekolah Tinggi Ilmu Kesehatan Kendal \\ 2 Program Studi Sarjana Farmasi Sekolah Tinggi Ilmu Kesehatan Kendal. \\ yulias.kepns@yahoo.co.id
}

\begin{abstract}
Abstrak
Masyarakat memiliki peran penting dalam pembangunan nasional. Salah satu bagian yang tidak terpisahkan dalam pembangunan nasional adalah status kesehatan. Gerakan masyarakat hidup sehat (GERMAS) merupakan program peningkatan status kesehatan berbasis masyarakat. Pemerintah Jawa Tengah menetapkan indikator GERMAS di Jawa Tengah yaitu ABCDEF yang merupakan singkatan dari Aktivias Fisik rutin 30 menit sehari, Banyak konsumsi sayur setiap hari, Cek Kesehatan, Diberikannya ASI ekseklusif, Enyahlah secepatnya asap rokok dan Fokus pada pencegahan stunting. Penelitian ini bertujuan untuk mengetahui perbedaan perilaku masyarakat dalam pelaksanaan GERMAS rural dan urban. Rancangan cross sectional digunakan untuk mengumpulkan data dengan variabel karakter perilaku masyarakat melakukan GERMAS di daerah rural dan urban. Lokasi penelitian di Desa Plantaran Kaliwungu Selatan dan Kelurahan Bugangin Kendal. Responden berjumlah 288 orang. Pengumpulan data menggunakan kuesioner. Analisis data menggunakan software komputer. Uji statistik yang digunakan adalah chi square untuk mengetahui perbedaan perilaku GERMAS pada masyarakat rural dan urban. Hasil penelitian menunjukkan bahwa terdapat perbedaan perilaku gerakan masyarakat hidup sehat pada masyarakat rural dan kelompok masyarakat urban $(p=0,001)$. Perlu dilakukan edukasi tentang indikator perilaku gerakan masyarakat hidup sehat, sehingga masyarakat dapat menjalani kehidupan secara sehat sesuai program yang dijalankan oleh pemerintah.
\end{abstract}

Kata kunci: GERMAS; rural; urban.

\begin{abstract}
The community has an important role in national development. One of the inseparable part of national development is health status. The Healthy Living Community Movement (GERMAS) is a community-based health status improvement program. The Central Java goverment sets the GERMAS indicator in Central Java, namely ABCDEF which stands for routine physical activity for 30 minutes a day, lots of vegetable comsumption every day, health checks, giving exclusive breastfeeding, get rid of ciggarette smoke as soon as possible and focus on preventing stunting. This study aims to determine the differences in communty behavior in the implementation of rural and urban GERMAS. Cross sectional design was used to collect data on the variable character behavior of the community in GERMAS in rural and urban areas. Location of this research is in the village of Plantaran Kaliwungu Selatan and Bugangin Kendal. Respondents in this study amounted to 288 people. Data collected with a questionnaire. Data analysis using computer software. The statistical test used is the chi square test to determine the differences
\end{abstract}


in GERMAS behavior in rural and urban communities. The results showed that there were differences in the behavior of the healthy life movement in rural and urban $(p=0,001)$. Education needs to be carried out on indicators of the behavior of community movement to live a healthy life, so that people can live a healthy life according to the programs run by the goverment.

Key words : GERMAS; rural; urban

\section{Pendahuluan}

Masyarakat merupakan bagian penting yang tidak terpisahkan dalam mencapai tujuan pembangunan nasional. Salah satu pembangunan yang dilakukan oleh pemerintah adalah bidang kesehatan. Tujuan pembangunan dibidang kesehatan adalah meningkatkan kesadaran dan kemampuan masyarakat dalam manjalani hidup sehat yang bermuara pada terciptanya derajat kesehatan masyarakat yang tinggi (Kemenkes, 2017).

Indonesia memiliki jumlah penduduk yang besar. Pertambahan jumlah penduduk menimbulkan berbagai permasalahan, salah satunya adalah. masalah kesehatan. Dalam 30 tahun terkahir Indonesia mengalami perubahan pola penyakit. Saat ini, penyebab kematian terbesar adalah penyakit tidak menular (PTM). Pada tahun 2030 diprediksi akan terjadi peningkatan penyakit tidak menular. Masalah tersebut menjadi tantangan tersendiri dan membutuhkan strategi untuk menekan laju pertambahan jumlah penyakit. Jika tidak diatasi maka akan berdampak pada kestabilan dalam berbagai bidang salah satunya adalah bidang ekonomi. Strategi penanganan yang tepat akan mampu menekan pertumbuhan penyakit tidak menular (Herayana, 2017).

Program yang diciptakan pemerintah untuk menekan masalah kesehatan akibat laju pertumbuhan jumlah penduduk dan penyakit tidak menular adalah gerakan masyarakat hidup sehat (GERMAS). Program GERMAS merupakan strategi yang terencana dan dijalankan dalam jangka panjang. Terdapat 7 indikator dalam gerakan germas yaitu: melakukan aktivitas fisik, mengkonsumsi sayur dan buah, tidak merokok, tidak mengkonsumsi alkohol, memeriksa kesehatan, membersihkan lingkungan tempat tinggal dan menggunankan sarana jamban (Kemenkes, 2017). Keberhasilan program GERMAS dapat menekan masalah kesehatan dan kematian penyakit tidak menular. Pada periode tahun 1990-2015 terjadi peningkatan kematian akibat penyakit tidak menular dari $37 \%$ menjadi 57 $\%$. Kematian akibat penyakit menular mengalami penurunan.

Angka PTM di Indonesia didominasi didaerah rural dengan angka presentase $60 \%$ dan daerah urban sebesar 40\% (Kemenkes RI, 2019). Tren kejadian penyakit tidak menular di Kabupaten Kendal adalah hipertensi dan diabetes mellitus (Dinkes Kab.Kendal, 2017). Penelitian oleh Hastuti, Susanti dan Iqomh (2019) menunjukkan gambaran gerakan masyarakat hidup sehat di Kelurahan Karangsari Kabupaten Kendal dalam kategori kurang baik. Gerakan masyarakat hidup sehat saat ini belum dilaksanakan secara 
maksimal. Oleh karena itu, peneliti melakukan penelitian yang bertujuan untuk mengetahui perbedaan perilaku gerakan masyarakat sehat di wilayah urban dan di wilayah rural.

\section{Metode}

Jenis penelitian ini adalah observasional analitik dengan pendekatan cross sectional. Jumlah sampel 288, yang terbagi menjadi dua kelompok rural dan urban. Teknik pengambilan sampel menggunakan purposive sampling dengan rincian responden antara lain kelompok masyarakat rural sebanyak 144 responden masyarakat desa Plantaran Kaliwungu Selatan dan kelompok masyarakat urban sebanyak 144 responden masyarakat Kelurahan Bugangin Kendal. Alat pengumpulan data pada penelitian ini menggunakan kuesioner. Kuesioner yang terdiri dari 15 pertanyaan dengan jenis pertanyaan tertutup. Pilihan jawaban menggunakan skala Guttman yang terdiri dari 2 pilihan jawaban yaitu "Ya" atau "Tidak".

Hasil uji validitas dengan menggunakan sampel sebanyak 20 responden didapatkan hasil yaitu 15 item pertanyaan dinyatakan valid dengan nilai $r$ lebih besar dari 0,361 dengan taraf kesalahan 5\% dengan nilai 0,384-0,760. Sedangkan hasil uji reliabilitas didapatkan hasil 0,646, hasil tersebut lebih besar dari 0,5 atau mendekati angka satu sehingga dinyatakan reliable. Pada penilitian ini dilakukan uji internal consistency yaitu mengujikan instrumen sekali saja. Jika hasil perhitungan mendekati nilai 1 maka dianggap reliabel. Untuk menentukan reliabilitas terhadap butirbutir pernyataan variabel dilakukan pengujian dengan Cronbach's Alpha.
Perbedaan perilaku kedua kelompok dianalisis menggunakan uji chi-square test.

\section{Hasil}

\section{Deskripsi Karakteristik Masyarakat Rural atau Pedesaan}

Tabel 1. Distribusi Responden Berdasarkan Usia Kelompok Masyarakat Rural Desember 2020 (N= 144)

\begin{tabular}{cccc}
\hline Variabel & Mean & SD & $\begin{array}{c}\text { Min- } \\
\text { Max }\end{array}$ \\
\hline Usia & 39,50 & 10,71 & $20-60$ \\
\hline
\end{tabular}

Tabel 2. Distribusi Responden Berdasarkan Jenis Kelamin dan Status Perkawinan, Kelompok Masyarakat Rural Desember 2020 (N=144)

\begin{tabular}{lcc}
\hline \multicolumn{1}{c}{ Variabel } & $\begin{array}{c}\text { Frek } \\
\text { (F) }\end{array}$ & $\begin{array}{c}\text { Persentas } \\
\text { e (\%) }\end{array}$ \\
\hline $\begin{array}{l}\text { Jenis } \\
\text { kelamin }\end{array}$ & & \\
\hline \multicolumn{1}{c}{ Laki-laki } & 73 & 50,7 \\
\hline $\begin{array}{l}\text { Perempu } \\
\text { an }\end{array}$ & 71 & 49,3 \\
\hline $\begin{array}{l}\text { Perkawinan } \\
\text { Belum } \\
\text { menikah }\end{array}$ & 8 & 5,6 \\
\hline Menikah & 133 & 92,4 \\
\hline $\begin{array}{l}\text { Berpisah } \\
\text { Total }\end{array}$ & 3 & 2,1 \\
\hline
\end{tabular}


Tabel 3. Distribusi Responden Berdasarkan Pendidikan, Pekerjaan, Penghasilan Kelompok Masyarakat Rural Desember 2020 (N=144)

\begin{tabular}{|c|c|c|}
\hline Variabel & $\begin{array}{c}\text { Frek } \\
\text { (F) }\end{array}$ & $\begin{array}{c}\text { Persentas } \\
\text { e (\%) }\end{array}$ \\
\hline \multicolumn{3}{|l|}{ Pendidikan } \\
\hline $\begin{array}{l}\text { Tidak } \\
\text { sekolah }\end{array}$ & 5 & 3,5 \\
\hline SD & 15 & 10,4 \\
\hline SMP & 36 & 25,0 \\
\hline SMA & 80 & 55,6 \\
\hline PT & 8 & 5,6 \\
\hline \multicolumn{3}{|l|}{ Pekerjaan } \\
\hline PNS & 2 & 1,4 \\
\hline Petani & 13 & 9,0 \\
\hline Pelajar & 1 & 0,7 \\
\hline Mahasiswa & 2 & 1,4 \\
\hline Buruh & 109 & 75,7 \\
\hline $\begin{array}{l}\text { Wiraswast } \\
\mathrm{a}\end{array}$ & 10 & 6,9 \\
\hline Lainnya & 7 & 4,9 \\
\hline \multicolumn{3}{|l|}{ Penghasilan } \\
\hline $\begin{array}{l}\text { Tidak } \\
\text { berpengha } \\
\text { silan }\end{array}$ & 6 & 4,2 \\
\hline $\begin{array}{l}\text { Kurang } \\
\text { dari UMK }\end{array}$ & 58 & 40,3 \\
\hline $\begin{array}{l}\text { Lebih dari } \\
\text { UMK }\end{array}$ & 80 & 55,6 \\
\hline Total & 144 & 100 \\
\hline
\end{tabular}

Tabel 1 dan 2 diatas menunjukkan bahwa karakteristik masyarakat rural atau pedesaan usia rata-rata 39,5 tahun, mayoritas responden berjenis kelamin laki-laki sebanyak 73 responden $\quad(50,7 \quad \%)$, status perkawinan menikah sebanyak 133 responden $(92,4 \%)$, berpendidikan SMA sebanyak 80 (55,6\%), bekerja sebagai buruh sebanyak 109 (75,7 $\%)$, memiliki penghasilan lebih dari UMK sebanyak 80 (55,6 \%).

Tabel 3. Distribusi Responden Berdasarkan Perilaku GERMAS Kelompok Masyarakat Rural Desember $2020(\mathrm{~N}=144)$

Aktifitas
Fisik

\section{Cek}

Kesehatan

Berkala

\begin{tabular}{ccc}
\hline $\begin{array}{c}\text { Tidak } \\
\text { dilakukan }\end{array}$ & 91 & 63,2 \\
\hline Dilakukan & 53 & 36,8 \\
\hline $\begin{array}{l}\text { Enyahkan } \\
\text { Asap Rokok }\end{array}$ & & \\
\hline $\begin{array}{c}\text { Tidak } \\
\text { dilakukan }\end{array}$ & 124 & 86,1 \\
\hline Dilakukan & 20 & 13,9 \\
\hline $\begin{array}{l}\text { Pencegahan } \\
\text { Stunting }\end{array}$ & & \\
\hline $\begin{array}{l}\text { Tidak } \\
\text { dilakukan }\end{array}$ & 115 & 79,9 \\
\hline
\end{tabular}




\begin{tabular}{lcc}
\hline \multicolumn{1}{c}{ Dilakukan } & 29 & 20,1 \\
\hline $\begin{array}{l}\text { Perilaku } \\
\text { GERMAS }\end{array}$ & & \\
\hline Kurang baik & 105 & 72,9 \\
\hline Baik & 39 & 27,1 \\
\hline Total & 144 & 100 \\
\hline
\end{tabular}

Tabel 3 diatas menunjukkan bahwa perilaku GERMAS masyarakat rural atau pedesaan mayoritas aktifitas fisik (64,6\%), cek kesehatan berkala $(63,2 \%)$, enyahkan asap rokok $(86,1 \%)$ dan pencegahan stunting $(79,9 \%)$ responden dalam kategori tidak dilakukan, dan hanya mengkonsumsi buah dan sayur dalam kategori dilakukan (74,3\%), sehingga disimpulkan bahwa perilaku GERMAS mayoritas tidak baik sebanyak 105 responden $(72,9 \%)$.

Tabel 4. Distribusi Responden Berdasarkan Usia Kelompok Masyarakat Urban Desember $2020(\mathrm{~N}=144)$

\begin{tabular}{lccc}
$\begin{array}{c}\text { Variabe } \\
\mathbf{l}\end{array}$ & Mean & $\boldsymbol{S D}$ & $\begin{array}{c}\text { Min- } \\
\text { Max }\end{array}$ \\
\hline Usia & 42,91 & 9,83 & $23-60$
\end{tabular}

Tabel 5. Distribusi Responden Berdasarkan Jenis Kelamin, Perkawinan, dan Pendidikan Kelompok Masyarakat Urban Desember 2020 (N=144)

\begin{tabular}{lcc}
\hline \multicolumn{1}{c}{ Variabel } & $\begin{array}{c}\text { Frek } \\
\text { (F) }\end{array}$ & $\begin{array}{c}\text { Persentase } \\
\text { (\%) }\end{array}$ \\
\hline $\begin{array}{l}\text { Jenis } \\
\text { kelamin }\end{array}$ & & \\
\hline \multicolumn{1}{c}{ Laki-laki } & 38 & 26,4 \\
\hline $\begin{array}{l}\text { Perempu } \\
\text { an }\end{array}$ & 106 & 73,6 \\
\hline
\end{tabular}

\begin{tabular}{ccc}
\hline Variabel & $\begin{array}{c}\text { Frek } \\
\text { (F) }\end{array}$ & $\begin{array}{c}\text { Persentase } \\
\text { (\%) }\end{array}$ \\
\hline Perkawinan & & \\
\hline Menikah & 140 & 97,2 \\
\hline Berpisah & 2 & 1,4 \\
\hline $\begin{array}{l}\text { Belum } \\
\text { menikah }\end{array}$ & 2 & 1,4 \\
\hline Pendidikan & & \\
\hline $\begin{array}{l}\text { Tidak } \\
\text { sekolah }\end{array}$ & 20 & 13,9 \\
\hline SD & 4 & 2,8 \\
\hline SMP & 10 & 6,9 \\
\hline SMA & 104 & 72,2 \\
\hline PT & 6 & 4,2 \\
\hline Total & 144 & 100 \\
\hline
\end{tabular}

Tabel 6. Distribusi Responden Berdasarkan Pekerjaan, dan Penghasilan Kelompok Masyarakat Urban Desember 2020 (N=144)

\begin{tabular}{ccc} 
Variabel & Frek & Persentas \\
& (F) & e (\%) \\
\hline
\end{tabular}

Pekerjaan

\begin{tabular}{lcc}
\hline PNS & 6 & 4,2 \\
\hline Petani & 2 & 1,4 \\
\hline Pelajar & 0 & 0 \\
\hline Mahasiswa & 0 & 0 \\
\hline Buruh & 102 & 70,8 \\
\hline $\begin{array}{l}\text { Wiraswast } \\
\text { a }\end{array}$ & 15 & 10,4 \\
\hline Lainnya & 19 & 13,2 \\
\hline
\end{tabular}

\section{Penghasilan}

Tidak berpengha 32,1 silan 


\begin{tabular}{ccc}
\hline Variabel & $\begin{array}{c}\text { Frek } \\
\text { (F) }\end{array}$ & $\begin{array}{c}\text { Persentas } \\
\text { e (\%) }\end{array}$ \\
\hline $\begin{array}{l}\text { Kurang } \\
\text { dari UMK }\end{array}$ & 95 & 66,0 \\
\hline $\begin{array}{l}\text { Lebih dari } \\
\text { UMK }\end{array}$ & 46 & 31,9 \\
\hline Total & 144 & 100 \\
\hline
\end{tabular}

Tabel 4, 5 dan 6 diatas menunjukkan bahwa karakteristik masyarakat urban rata-rata usia responden adalah 42,91 tahun, mayoritas responden berjenis kelamin perempuan sebanyak 106 responden $(73,6 \%)$, status perkawinan menikah sebanyak 140 responden $(97,2$ $\%$ ), berpendidikan SMA sebanyak 104 responden $(72,2 \%)$, bekerja sebagai buruh sebanyak 102 responden (70,8 $\%)$, memiliki penghasilan kurang dari UMK sebanyak 95 responden (66,0\%).

Tabel 7. Distribusi Responden Berdasarkan Perilaku GERMAS Kelompok Masyarakat Urban Desember $2020(\mathrm{~N}=144)$

\begin{tabular}{|c|c|c|}
\hline $\begin{array}{l}\text { Aktifitas } \\
\text { Fisik } \\
\end{array}$ & & \\
\hline $\begin{array}{l}\text { Tidak } \\
\text { dilakukan }\end{array}$ & 99 & 68,8 \\
\hline Dilakukan & 45 & 33,3 \\
\hline $\begin{array}{l}\text { Mengkonsu } \\
\text { msi Buah } \\
\text { dan Sayur }\end{array}$ & & \\
\hline $\begin{array}{l}\text { Tidak } \\
\text { dilakukan }\end{array}$ & 16 & 11,1 \\
\hline Dilakukan & 128 & 88,9 \\
\hline $\begin{array}{l}\text { Cek } \\
\text { Kesehatan } \\
\text { Berkala }\end{array}$ & & \\
\hline
\end{tabular}

\begin{tabular}{lcc}
\hline $\begin{array}{c}\text { Tidak } \\
\text { dilakukan }\end{array}$ & 16 & 11,1 \\
\hline \multicolumn{1}{c}{ Dilakukan } & 128 & 88,9 \\
\hline $\begin{array}{l}\text { Enyahkan } \\
\text { Asap Rokok }\end{array}$ & & \\
\hline $\begin{array}{l}\text { Tidak } \\
\text { dilakukan }\end{array}$ & 86 & 59,7 \\
\hline \multicolumn{1}{c}{ Dilakukan } & 58 & 40,3 \\
\hline $\begin{array}{l}\text { Pencegahan } \\
\text { Stunting }\end{array}$ & & \\
\hline $\begin{array}{l}\text { Tidak } \\
\text { dilakukan }\end{array}$ & 114 & 79,2 \\
\hline \multicolumn{1}{c}{ Dilakukan } & 30 & 20,8 \\
\hline $\begin{array}{l}\text { Perilaku } \\
\text { GERMAS }\end{array}$ & & \\
\hline $\begin{array}{l}\text { Kurang baik } \\
\text { Baik }\end{array}$ & 65 & 54,9 \\
\hline \begin{tabular}{l} 
Total \\
\hline
\end{tabular} & 144 & 100 \\
\hline
\end{tabular}

Tabel 7 diatas menunjukkan bahwa perilaku GERMAS masyarakat urban atau perkotaan mayoritas aktifitas fisik $(68,8 \%)$, enyahkan asap rokok $(59,7 \%)$ dan pencegahan stunting $(79,2 \%)$ responden dalam kategori tidak dilakukan, dan hanya mengkonsumsi buah dan sayur $(88,9 \%)$, cek kesehatan berkala $(88,9 \%)$ dalam kategori dilakukan, sehingga disimpulkan bahwa perilaku GERMAS mayoritas kurang baik sebanyak 79 responden (54,9\%).

Data penelitian yang diperoleh dari responden menggunakan kuesioner kemudian dilakukan analisis dengan menggunakan uji chi-square test. Hasil uji analisis dapat dilihat ditabel dibawah ini: 
Tabel 8. Perbedaan Perilaku GERMAS masyarakat Rural dan Urban

\begin{tabular}{lccc}
\hline Perilaku GERMAS & Rural & Urban & p-Value \\
\cline { 1 - 3 } Kurang Baik & 105 & 79 & 0,001 \\
\cline { 1 - 3 } & $(72,9 \%)$ & $(54,9 \%)$ & \\
\hline \multirow{2}{*}{ Baik } & 39 & 65 & \\
& $(27,1 \%)$ & $(45,1 \%)$ & \\
\hline
\end{tabular}

Tabel 8. Hasil nilai $p$-value menunjukkan angka sebesar 0,001. Nilai tersebut lebih kecil dari nilai alpha yaitu 0,05. Kesimpulan berdasar hasil analisis adalah terdapat perbedaan perilaku GERMAS antara kelompok masyarakat dengan rural kelompok masyarakat urban.

\section{Pembahasan}

\section{Karakteristik Responden}

Hasil penelitian menunjukkan karakteristik masyarakat rural atau pedesaan usia rata-rata 39,5 tahun, mayoritas responden berjenis kelamin laki-laki sebanyak 73 responden $(50,7$ $\%)$ status perkawinan menikah sebanyak 133 responden $(92,4 \%)$, berpendidikan SMA sebanyak 80 (55,6 \%), bekerja sebagai buruh sebanyak 109 $(75,7 \%)$, memiliki penghasilan lebih dari UMK sebanyak $80 \quad$ (55,6 \%). Sedangkan karakteristik masyarakat urban menunjukkan rata-rata usia responden adalah 42,91 tahun, mayoritas responden berjenis kelamin perempuan sebanyak 106 responden $(73,6 \%)$, status perkawinan menikah sebanyak 140 responden $(97,2 \%)$, berpendidikan SMA sebanyak 104 responden $(72,2 \%)$, bekerja sebagai buruh sebanyak 102 responden (70,8 $\%)$, memiliki penghasilan kurang dari UMK sebanyak 95 responden $(66,0 \%)$.

Karakteristik usia responden tersebut dalam kategori usia dewasa akhir, sesuai rentang usia 36 tahun - 45 tahun (Depkes, 2009). Hasil penelitian sama seperti penelitian yang dilakukan oleh Hastuti, Susanti dan Iqomh (2019) tentang gambaran gerakan masyarakat hidup sehat di Kelurahan Karangsari Kabupaten Kendal, juga mendapatkan hasil rata-rata responden berusia 45 tahun. Sesuai dengan teori Padila (2013) menyatakan bahwa usia dewasa akhir akibat perubahan fisik yang menua maka perubahan ini akan sangat berpengaruh pada peran dan hubungan dirinya dengan lingkungan. Notoatmodjo (2010) menyebutkan bahwa perubahan umur mempengaruhi peran dan perilaku seseorang melalui perjalanan umurnya yang disebabkan oleh proses pendewasaan.

Karakteritik jenis kelamin dalam penelitian menunjukkan ada perbedaan antara rural dan urban. Didaerah rural mayoritas laki-laki dan didaerah urban mayoritas perempuan. Hal ini berdasarkan survei di lapangan saat pengambilan data, di daerah rural atau pedesaan seorang perempuan atau ibu 
cenderung tidak bersedia menjadi responden karena keputusan keluarga ada di kepala keluarga. Hal ini dipengaruhi oleh budaya atau kebiasaan masyarakat. Budaya pengambilan keputusan didalam keluarga didominasi oleh kepala keluarga yaitu suami. Peran kepala keluarga menjadi pusat dalam pengambilan keputusan, hal ini bertujuan untuk mendapatkan keputusan yang tepat. Meskipun demikian, keputusan dalam rumah tangga tidak selalu ditentukan oleh suami sebagai kepala keluarga (Retnowulandari, 2016).

Karakteristik status perkawinan mayoritas responden menunjukkan sudah menikah. Dengan status menikah secara tidak langsung sudah berkeluarga dan memiliki tanggung jawab dan peran didalam keluarga. Status sudah menikah ini menunjukkan bahwa yang sudah menikah pasti lebih sadar akan pentingnya melakukan atau berperilaku GERMAS dengan baik, dibandingkan yang belum menikah. Sesuai dengan teori HL Blum terdapat 4 faktor yang mempengaruhi status kesehatan derajat kesehatan masyarakat atau perseorangan. Faktor tersebut adalah lingkungan, perilaku, pelayanan kesehatan, dan keturunan. Lingkungan sebagai salah satu faktor yang memperngaruhi kesehatan dapat dikendalikan melalui perilaku sehingga menjadi kebiasaan hidup.

Karakteristik pendidikan responden mayoritas SMA baik masyarakat rural dan urban. Hasil penelitian ini menunjukkan bahwa masyarakat memiliki tingkat pendidikan yang setara yaitu tingkat pendidikan menengah. Berdasarkan teori Wawan (2010) menunjukkan bahwa pendidikan akan mempengaruhi perilaku seseorang akan pola hidup. Hasil penelitian ini didukung oleh penelitian Hastuti, Susanti dan Iqomh (2019) dan Ratnawati, Maryati dan Mahardika (2013) menyatakan bahwa sebagaian besar responden berpendidikan menengah (SMA). Responden yang berpendidikan SMA akan memperngaruhi perilaku keluarga dalam menerapkan gerakan masyarakat perilaku hidup sehat karena memiliki wawasan yang cukup.

Karakteristik pekerjaan responden mayoritas sebagai buruh pabrik baik masyarakat rural dan urban. Hasil penelitian ini menunjukkan bahwa masyarakat memiliki pekerjaan yang sama atau setara yaitu sebagai buruh pabrik. Karakteristik penghasilan responden dalam peneltian ini ada perbedaan antara rural dan urban. Dimana didaerah rural rata-rata penghasilan diatas UMK dan didaerah urban rata-rata dibawah UMK. Hal ini dipengaruhi oleh jenis pekerjaan responden. Pendapatan kepala keluarga yang mempengaruhi dalam melakukan gerakan masyarakat hidup sehat seperti halnya pendapat Hartono (2008) yang menyatakan bahwa pendapatan keluarga salah satu faktor yang mempengaruhi daya beli keluarga dalam menyediakan kebutuhan kesehatan keluarga.

\section{Perilaku GERMAS}

Hasil penelitian menunjukkan bahwa Perilaku GERMAS masyarakat daerah rural atau pedesaan mayoritas dalam kategori tidak baik sebanyak 105 responden $(72,9 \%)$ dan masyarakat urban atau perkotaan mayoritas dalam kategori kurang baik yaitu sebanyak 79 responden (54,9\%). Berdasarkan hasil 
analisis terdapat perbedaan perilaku GERMAS antara kelompok masyarakat dengan rural kelompok masyarakat urban. Dapat disimpulkan bahwa adanya perbedaaan perilaku masyarakat rural dan urban. Dalam penelitian Perilaku GERMAS ini terdapat 5 indikator dalam perilaku GERMAS yaitu: melakukan aktivitas fisik, mengkonsumsi sayur dan buah, tidak merokok, memeriksa kesehatan, dan pencegahan stunting.

Hasil penelitian ini menunjukkan bahwa perilaku GERMAS aktifitas fisik masyarakat rural atau pedesaan $(64,6 \%)$, dan masyarakat urban atau perkotaan $(68,8 \%)$ dalam kategori tidak dilakukan sesuai dengan tabel 3 dan 7 . Sehingga disimpulkan bahwa perilaku GERMAS Aktifitas Fisik dalam kategori kurang baik. Responden lebih banyak tidak melakukan aktifitas fisik berolahraga, bersepeda, jalan ringan selama 30 menit. Hasil penelitian sama seperti penelitian Sidaria dan Hidayati (2019) melaporkan keluarga di RW 8 Kelurahan Kubu Marapalam dengan penerapan GERMAS kurang baik, terutama dalam aktifitas fisik, sebanyak 42 responden (57\%) dan baik sebanyak 31 responden (42,5\%). Hasil penelitian lain Tedi, Fadly dan Ridho (2018) menunjukkan bahwa masyarakat di wilayah kerja Puskesmas Kecamatan Sukarame Palembang memiliki kebiasaan baik dalam melakukan aktivitas fisik setiap hari dan Puskesmas Talang Betutu memiliki presentase yang tertinggi dalam pelaksanaan indikator ini. Namun aktivitas senam sehat bugar belum dilakukan secara rutin oleh masing-masing Puskesmas dan kurangnya kesadaran masyarakat. Berdasarkan penelitian Mila, Aninda dan Ernawati (2016) menunjukkan bahwa beberapa hal yang dapat mempengaruhi aktifitas diantaranya adalah jenis kelamin, pekerjaan, pendidikan. Sedangkan menurut Kemenkes RI (2016) aktifitas fisik yang sehat adalah setiap gerakan tubuh yang melibatkan otot rangka dan mengakibatkan pengeluaran energi seperti maraton, jalan santai dan senam yang bisa dilakukan selama 30 menit setiap hari.

Hasil penelitian ini menunjukkan bahwa perilaku GERMAS mengkonsumsi buah dan sayur masyarakat rural atau pedesaan $(74,3 \%)$ dan masyarakat urban atau perkotaan (88,9\%), dalam kategori dilakukan. Sehingga disimpulkan bahwa perilaku GERMAS mengkonsumsi buah dan sayur dalam kategori mayoritas baik berdasarkan tabel 3 dan 7 bahwa sebagian besar responden mengkonsumsi buah dan sayur sesuai dengan porsinya. Hasil penelitian ini menunjukkan bahwa masyarakat mengkonsumsi buah dan sayur setiap hari. Kemenkes RI (2016) rekomendasi kecukupan konsumsi buah dan sayur adalah 300-400 gram perorang perhari. Konsumsi buah dan sayur dianjurkan sebanyak 2 porsi setiap hari, dalam satu kali makan mengandung $1 / 3$ untuk makanan pokok, $1 / 3$ untuk sayuran, dan $1 / 3$ untuk lauk dan buah akan membantu mencegah penyakit tidak menular kronik seperti kanker usus.

Hasil penelitian menunjukkan perilaku GERMAS cek kesehatan berkala masyarakat rural atau pedesaan mayoritas tidak dilakukan $(63,2 \%)$ dan masyarakat urban atau perkotaan cek kesehatan berkala mayoritas dalam kategori dilakukan $(88,9 \%)$. Sehingga disimpulkan bahwa perilaku GERMAS cek kesehatan berkala masyarakat rural dan urban ada perbedaan. Hasil 
penelitian lain yang mendukung Tamnge dan Munir (2018) menunjukkan hasil bahwa ada hubungannya pelayanan kesehatan dengan melakukan pemeriksaan kesehatan rutin dengan baik. Sebagian besar responden melakukan pemeriksaan kesehatan rutin dengan baik sebanyak 20 responden. Pemeriksaan kesehatan yang dimaksud memiliki beberapa indikator seperti pengukuran IMT, pengukuran tekanan darah, pemeriksaan kadar gula darah, kadar kolesterol darah, dan kadar asam urat.

Pemeriksaan kesehatan secara rutin bertujuan untuk mendeteksi berbagai penyakit dalam tubuh, dan membantu mencegah berkembangnya penyakit dalam tubuh, pemeriksaan kesehatan secara rutin yaitu dilakukan sebanyak 6 bulan sekali dilakukan oleh individu $>15$ tahun pemeriksaannya meliputi cek tekanan darah, gula darah, kolesterol, darah lengkap, lingkar perut dan Inspeksi Visual Asam Cuka (IVA) Kemenkes RI (2016).

Hasil penelitian ini menunjukkan bahwa perilaku GERMAS masyarakat rural atau pedesaan dan masyarakat urban atau perkotaan mayoritas kurang baik dan adanya perbedaan yang signifikan antara masyarakat rural dan urban. Hal ini didukung oleh hasil penelitian Cokroadhisuryani (2018), menunjukkan bahwa kegiatan Germas yang dilakukan oleh Puskesmas Ngaglik, dalam pelaksanaannya kurangnya kesadaran masyarakat dalam pelaksanaan Germas dan keterbatasan dana serta sumberdaya. Indikator Germas yang digunakan yaitu Perilaku hidup bersih dan sehat rumah tangga.

Hasil penelitian yang sama didaerah rural Tedi, Fadly dan Ridho (2018) menunjukkan bahwa masyarakat di wilayah kerja Puskesmas Kecamatan Sukarame Palembang memiliki kebiasaan baik dalam melakukan aktivitas fisik setiap hari. Namun aktivitas senam sehat bugar belum dilakukan secara rutin dan kurangnya kesadaran masyarakat. Kebiasaan mengkonsumsi buah 2-3 kali dalam sehari masih sangat jarang dilakukan masyarakat. Kebiasaan masyarakat baik dalam melakukan pemeriksaan kesehatan secara rutin setiap enam bulan sekali, walaupun masih ada yang belum melakukannya. Hasil penelitian ini menujukkan pelaksanaan GERMAS di daerah pedesaan sebagian kurang baik.

Hasil penelitian lain yang mendukung terkait pelaksanaan GERMAS Rahmawaty, Handayani, Sari dan Rahmawati (2019) menunjukkan bahwa GERMAS merupakan gerakan nasional yang tidak bisa hanya mengandalkan peran sektor kesehatan saja. Peran kementerian dan lembaga di sektor lainnya juga turut menentukan dan ditunjang peran serta masyarakat dalam mempraktekkan pola hidup sehat. Dengan sosialisasi Germas dan PIS PK diharapkan mampu mengajak masyarakat untuk membudayakan hidup sehat, agar mampu mengubah kebiasaan atau perilaku tidak sehat.

Adanya perbedaan perilaku antara masyarakat rural dan urban dipengaruhi oleh beberapa faktor. Masyarakat pedesaan kehidupannya berbeda dengan masyarakat perkotaan. Perbedaan-perbedaan ini berasal dari adanya perbedaan yang mendasar dari keadaan lingkungan, yang mengakibatkan adanya dampak terhadap personilitas dan segi-segi kehidupan. Hasil penelitian ini menunjukkan adanya perbedaan 
pelaksanaan gerakan masyarakat hidup sehat. Masyarakat perkotaan atau urban lebih banyak yang menerapkan perilaku gerakan masyarakat hidup sehat dengan baik meliputi melaksanakan aktifitas fisik secara rutin, mengkonsumsi buah dan sayur setiap hari, menghindari atau tidak menghirup asap rokok, melakukan pemeriksaan kesehatan secara rutin, dan melaksanakan pencegahan stunting.

\section{Simpulan}

Perilaku gerakan masyarakat hidup sehat (GERMAS) masyarakat rural maupun urban mayoritas kurang baik. Terdapat perbedaan perilaku gerakan masyarakat hidup sehat pada masyarakat rural dan urban.

\section{Saran}

Salah satu upaya yang bisa dilakukan untuk meningkatkan keberhasilan program ini adalah dengan meningkatkan pengetahuan masyarakat, menyediakan fasilitas pendukung dan melakukan pendampingan. Pengetahuan menjadi faktor penting untuk merubah perilaku seseorang, semakin meningkat pengetahuan maka peluang untuk merubah sikap dan perilaku akan semakin besar.

Penelitian tentang penyebab rendahnya perilaku gerakan masyarakat hidup sehat masih perlu dilakukan secara kontinyu. Penelitian bisa dilakukan untuk mencari penyebab rendahnya partisipasi masyarakat serta mencari metode yang efektif dan efisien untuk meningkatkan keberhasilanl program ini.

\section{Daftar Pustaka}

Ambarwati dan Prihastuti (2019). Gerakan Masyarakat Hidup Sehat (Germas) mencuci tangan menggunakan sabun dan air mengalir sebagai upaya untuk menerapkan perilaku hidup bersih dan sehat (PHBS) sejak dini. http://journal/lldikti9.id/CER/index Vol 1, No 1, April 2019 pp 45-52, p-ISSN: 2656-7938.

Cokroadhisuryani (2018), Analisis Pelaksanaan Gerakan masyarakat Hidup Sehat (GERMAS) di wilayah kerja Puskesmas Ngaglik I. dspace.uii.ac.id.

Dinas Kesehatan Kabupaten Kendal. (2017). Profil Dinas Kesehatan Kabupaten Kendal. DKK Kendal.

Herayana, A. (2017). Epidemologi Penyakit Tidak Menular. Kementerian Kesehatan Republik Indonesia; Jakarta.

Hastuti, NP. Susanti, Y. Iqomh, MKB. (2019). Gambaran Pelaksanaan Kegiatan Gerakan Masyarakat Hidup Sehat (GERMAS). J. Ilmiah STIKES Kendal. 2019;9(2):141-148.

Junita, Handayani dan Alfiah (2020). GERMAS (Gerakan Masyarakat Hidup Sehat) Di Desa Rambah Hilir. Dalam Kumawula: Jurnal Pengabdian Kepada Masyarakat Vo. 3 No 1 Tahun 2020 http://journal.unpad.ac.id/kumawula/i ssue/view.

https://doi.org/10.24198/kumawula.v3 $\underline{\mathrm{i} 1.24743}$

Kementerian Kesehatan Republik Indonesia. (2016). Buku Panduan Gerakan Masyarakat Hidup Sehat;Kemenkes RI; Jakarta.

Padila. (2013) Asuhan Keperawatan Penyakit Dalam. Yogyakarta: Nuha Medika.

Retnowulandari. Wahyuni. (2016) Kepala keluarga dalam hukum keluarga di Indonesia: tinjauan perspektif gender 
dalam hukum agama, adat, hukum nasional. J. Hukum Prioris.

Rahmawaty, Handayani, Sari dan Rahmawati (2019). Sosialisasi dan Harmonisasi Gerakan Masyarakat Hidup Sehat (Germas) dan Program Indonesia Sehat Dengan Pendekatan Keluarga (PISPK) Di Kota Sukabumi.

Sidaria dan Hidayati (2019). Tingkat Pengetahuan, Peran Petugas Kesehatan dan Penerapan GERMAS Di RW 8 Kelurahan Kubu Marapala. Ensiklopedia of Journal volume 2 Nomor 1 Edisi 2 Bulan Oktober Tahun 2019 http://jurnal.ensiklopediaku.org

Tamnge dan Munir (2018). Pelayanan Tenaga Kesehatan Dengan Pemeriksaan Kesehatan Rutin Dalam Program GERMAS di Sukolilo Tuban.

Tedi, Fadly dan Ridho (2018). Hubungan Program GERMAS terhadap kebiasaan hidup masyarakat yang telah dan belum mendapatkan sosialisasindi wilayah kerja puskesmas kecamatan sukarame Palembang. Jurnal kesehatan poltekkes palembang vol 13 No 1 tahun 2018. https://doi.org/10.36086/ipp.v13i1.77.

Zainul, Junaidi, Nasrul, Masudin (2019). Inisiasi Gerakan Masyarakat Sehat (GERMAS) di Poltekkes Kemenkes Palu. Vol 13 No 1 Bulan Mei Tahun 2019 halaman 54-61, https://doi.org/10.33860/jik.v13i1.33 http://jurnal.poltekkespalu.ac.id/index. $\mathrm{php} / \mathrm{IIK}$ 